\title{
Abbreviations and Note on Translations
}

ADG Archives départementales, Gironde

ADSL Archives départementales, Saône et Loire

AMD Archives municipales, Dijon

AML Archives municipales, Lyon

AMM Archives municipales, Mâcon

AMN Archives municipales, Nantes

AN Archives nationales, Paris

$\mathrm{BN}$ Bibliothèque nationale, Paris

For municipal and departmental archives that are less frequently cited, the abbreviations AD (archives départementales) and AM (archives municipales), followed by the place name, will be used (e.g., AD Côte d'Or).

I have retained the original spelling but modernized the punctuation in French quotations. Unless otherwise stated, all translations are my own. 

The Rites of Labor 
